\title{
Belchior and the
}

\section{Brazilian}

\section{military}

regime:

state

authoritarianis

$m$ and inter-

regional

migration in his

lyrics

Leandro Martan

Bezerra Santos ${ }^{1}$

brasileiro: autoritarismo estatal e a migração interregional em suas letras 



\section{Resumo:}

O presente artigo visa analisar a obra do músico Antônio Carlos Belchior, de acordo com um olhar centrado em aspectos das ciências humanas e sociais. Com uma metodologia de pesquisa explicativa e a partir do estudo das letras das músicas escritas por Belchior - empregando uma abordagem qualitativa sobre essas composições - pretende-se compreender de que maneiras Belchior dialogava com a sociedade brasileira, assim como há uma busca pelo entendimento de sua produção, rica em análises críticas sobre temas diversos como migração, e seu olhar sobre a ditadura civil-militar que perdurou no Brasil entre os anos 1964 e 1985, que afetou de maneira direta e indireta grande parte do seu período de carreira, seja na forma de censura de suas canções ou no próprio contexto vivenciado a partir do período inicial de sua vida adulta.

Palavras-chave: Belchior; ditadura militar; música popular brasileira.

\section{Abstract:}

This article aims to analyzing the work of the musician Antônio Carlos Belchior, according to a critical view focused on aspects of the human and social sciences. With an explanatory research methodology and using Belchior's writing of lyrics, employing a qualitative approach on these compositions, this work intends to understand in what ways Belchior dialogues with the Brazilian society, as well as attempts to understand his production, fully critical on diverse and pertinent themes such as migration and his unique view about the civil-military dictatorship in Brazil between 1964 and 1985, which affected directly and indirectly much of his career, either in the form of censorship of his songs, or in his own life experience in the initial period of his adult life.

Keywords: Belchior; Military dictatorship; Popular Brazilian music. 
Belchior e o regime militar brasileiro: autoritarismo estatal e a migração inter-regional em suas letras

\section{Introdução}

"Quem haverá que aguente tanta mudez sem perder a saúde?"

(Como se fosse pecado - Belchior)

"Pela geografia, aprendi que há, no mundo, um lugar onde um jovem como eu pode amar e ser feliz. Procurei passagem, avião, navio... não havia linha 'praquele' país"

(Caso comum de trânsito - Belchior)

Antônio Carlos Belchior nasceu em outubro de 1946, na cidade de Sobral, interior do estado do Ceará. Ainda na adolescência, saiu de sua cidade para ingressar nos estudos religiosos em monastérios de seu estado natal. Após os anos de contato direto com a religião, estudou Medicina na Universidade Federal do Ceará e deu início à sua carreira musical após frequentar os efervescentes locais de reunião de jovens músicos e estudantes na cidade de Fortaleza, onde conheceu figuras como Ednardo e Raimundo Fagner, além de outros talentosos artistas, familiarizando-se com o ambiente boêmio da capital. Sua primeira composição de sucesso, inclusive com o arranjo musical feito por Fagner, foi "Mucuripe", na qual espelhava momentos desse período e retratava "as velas do Mucuripe", praia em cuja orla se localizava o ponto de encontro musical preferido daquela geração cearense.

Em seguida, deu-se a participação do artista em festivais de música da região Nordeste, extremamente comuns e populares nas décadas de 1960 e 1970. Com o reconhecimento inicial das acirradas disputas e a diversão proporcionada pela rotina de viagens e competição musical, Belchior se sentiu motivado a tal ponto que decidiu sair da faculdade de Medicina para tentar a sorte e a carreira como músico no Sudeste do Brasil.

Ao chegar à região, porém, enfrentou grandes contratempos, uma vez que não contava com o auxílio financeiro da família - fruto de sua opção pessoal -, embora já tivesse sido premiado em festivais e regravado por artistas de destaque. Essa conjuntura composta por diversas contrariedades estava amplamente presente nas composições de sua autoria nesse período inicial no Sudeste, com diversos relatos e reflexões sobre as dificuldades de adaptação, a falta de recursos financeiros, o preconceito enfrentado por ser nordestino e os demais problemas presentes no cotidiano das grandes cidades brasileiras. 
Com canções autorais arrojadas e carregadas de peculiar sagacidade, a obra de Belchior se insere em inúmeros campos temáticos de debate, fazendo de sua música um instrumento de contestação política, social e histórica. A partir de uma reflexão acadêmica feita com base em discussões e pressupostos teóricos das ciências humanas e sociais, objetiva-se compreender e analisar Belchior e sua produção como intérprete das contradições, dificuldades e dilemas enfrentados pela população brasileira - com ênfase nas suas relações com o Estado -, além das maneiras pelas quais sua obra foi socialmente entendida e consagrada.

Especialmente após a morte do referido cantor, torna-se essencial proceder com um balanço acadêmico sobre sua extensa carreira. A partir do estudo das letras das músicas escritas por Belchior, e empregando uma abordagem qualitativa sobre essas composições, pretende-se analisar de que maneiras Belchior dialogava com a sociedade brasileira, expandindo o entendimento do conjunto de sua obra, rica em percepções críticas sobre temas diversos e pertinentes, mas pesquisada ainda de maneira relativamente incipiente, especialmente quando comparada ao número de trabalhos aos quais servem de tema artistas nacionais de semelhante magnitude.

Tal caminho metodológico resulta de uma valorização sobre a memória presente nas canções de Belchior, entendendo as características contextuais de sua escrita. A metodologia adotada na pesquisa se baseou em procedimentos de ordem bibliográfica e documental, através de leitura sobre vida e obra de Belchior e arranjos sociopolíticos nacionais das épocas de sua produção, do estudo de composições e referências do artista e de discussões teóricas acadêmicas, possibilitando um arranjo característico de uma pesquisa explicativa.

As fontes escolhidas para o embasamento teórico deste trabalho são as letras de todas as músicas compostas ou gravadas por Belchior, aproximadamente 120 canções que passaram por análise de suas letras, bem como obras que promovem balanços historiográficos da música brasileira, livros e textos acadêmicos que tratam de temas que competem às ciências sociais e humanas, com contribuições advindas das áreas de História, Geografia, Sociologia, Música e Comunicação. Teses, dissertações e artigos sobre o próprio Belchior - assim como sua biografia e entrevistas concedidas pelo cantor objeto deste estudo são outras importantes contribuições à análise aqui realizada. 
Belchior e o regime militar brasileiro: autoritarismo estatal e a migração inter-regional em suas letras

No entendimento de Marcos Napolitano, uma das abordagens fundamentais para o trabalho do pesquisador é aquela que leve em conta que:

\begin{abstract}
O sentido sociocultural, ideológico e, portanto, histórico, intrínseco de uma canção é produto de um conjunto indissociável que reúne: palavra (letra); música (harmonia, melodia, ritmo); performance vocal e instrumental (...) para o caso da pesquisa histórica, defendemos essa última abordagem, pois ela permite situar uma canção objeto da cultura, não isolando aspectos literários, linguísticos ou tecnológicos (NAPOLITANO, 2010, p. 271).
\end{abstract}

Por seus versos passam importantes ocorrências históricas e de dinâmicas sociais brasileiras, além de episódios vividos e sentimentos de ordem pessoal do cantor, estes comumente alinhados aos experimentados por muitos outros indivíduos, o que pode ajudar a explicar o sucesso de suas composições junto ao grande público. Também fazem parte de seu trabalho motivações temáticas como a de relacionamentos familiares, as angústias, indecisões e transições nas carreiras e nas escolhas das vidas dos indivíduos mais jovens, e eventuais digressões poéticas e artísticas próprias, constituindo-se em ferramentas auxiliares para a assimilação completa de suas intenções na formulação das canções.

A seguir, serão analisadas as tensas relações entre Belchior e a ditadura civilmilitar implantada no Brasil, a prática da censura e da perseguição política no período, sendo este um dos temas mais explorados e decisivos nas composições e na vida do artista. Além disso, a dinâmica das migrações inter-regionais, outro tema recorrente em sua obra, também ganha espaço no estudo e conta com análise própria.

\title{
A ditadura civil-militar, a censura e o protesto de Belchior
}

O período no qual o regime ditatorial civil-militar esteve no poder, oficialmente considerado entre 1964 e 1985, foi marcado pela intensa arbitrariedade e violência contra seus opositores, com vasto emprego de métodos de torturas, ampla censura à imprensa e às artes brasileiras, limitação da participação política e do exercício da cidadania, prisões arbitrárias, manipulação constitucional e supressão dos demais Poderes em favorecimento ao Executivo - o que culminou em interferência direta dos ditadores no Judiciário, cassação de mandatos e até mesmo a dissolução do Congresso Nacional - além de sistemáticos desaparecimentos e assassinatos de opositores. 
Com relação ao caráter da ditadura instaurada no Brasil, o historiador Daniel Aarão Reis aponta que:

\begin{abstract}
Na historiografia corrente, há um sendo comum: a ditadura no Brasil acabou em 1985, com a posse do primeiro presidente civil, José Sarney. A ideia subjacente é que a ditadura foi apenas militar, o que os fatos, decididamente, não evidenciam. Desde a sua gênese, passando pelos vários governos, pela análise dos seus promotores e beneficiários, a ditadura nunca foi obra apenas das casernas. Assim, o referido senso comum é muito mais obra de memória do que de resultado de pesquisa histórica (REIS, 2014, p. 103).
\end{abstract}

Dessa forma, as letras agressivas de Belchior não visavam provocar somente os militares detentores de poder, objetivando também sua crítica as parcelas da sociedade civil responsáveis pelo surgimento e sustentação do regime militar, sendo estes alvos a imprensa, os grandes empresários e industriais e as classes médias e altas urbanas, assim como todos aqueles que se resignavam perante o modelo político imposto. Para esses setores, Belchior mandava um recado expresso e direto na canção "A palo seco":

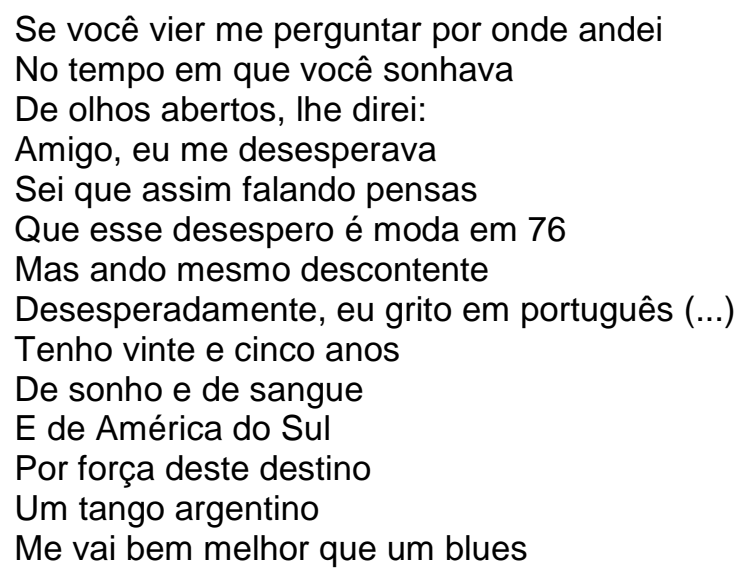

Esse tipo de alerta também se verificava nos versos de canções como "Todo sujo de batom", quando o autor diz: "Eu estou muito cansado / De não poder falar palavra"; em "Apenas um rapaz latino-americano", na qual Belchior ironiza: "Mas não se preocupe meu amigo / Com os horrores que eu lhe digo / Isto é somente uma canção / A vida realmente é diferente / Quer dizer, ao vivo é muito pior"; e em "Como nossos pais", quando o cantor adverte: "Por isso, cuidado, meu bem / Há perigo na esquina / Eles venceram / E o sinal está fechado pra nós / Que somos jovens".

Suas palavras, navalhas, atacam diretamente quem, em sua visão, aliena suas letras com relação aos problemas políticos e sociais do Brasil, e tem em assuntos 
Belchior e o regime militar brasileiro: autoritarismo estatal e a migração inter-regional em suas letras

relacionados à felicidade, ao amor e a situações banais do cotidiano o principal escopo temático de seus trabalhos. Não que tais conteúdos não estivessem presentes em seu trabalho ou fossem totalmente menosprezados por Belchior, mas estavam relegados ao segundo plano de sua produção, afastados de sua concepção sobre o papel contestador que cabe à música, conforme nos mostra o seguinte trecho da música "Conheço o meu lugar", do álbum "Era uma vez um homem e seu tempo", lançado no ano de 1979: "Não há motivo para festa: Ora, esta! / Eu não sei rir à toa! / Fique você com a mente positiva / Que eu quero é a voz ativa (ela é que é uma boa!)". A respeito do desenrolar do golpe civil-militar de 1964, Luiz Weis e Maria Hermínia de Almeida comentam que:

\begin{abstract}
Começou no dia 30 de março, quando o general Carlos Luís Guedes se preparou para marchar de Belo Horizonte a Brasília; prosseguiu na madrugada de 31, quando o general Olympio Mourão Filho deixou Juiz de Fora a caminho do Rio de Janeiro, e se estendeu ao dia 2, quando chuvas de papel picado cobriram o centro das principais cidades à medida que as últimas notícias das rádios, ouvidas por muitos milhares de pessoas, em casa, nos escritórios, nos bares e nas lojas, confirmavam que o presidente João Goulart partiria para o Uruguai e que os militares se preparavam para assumir o controle político do país. Mas, enquanto setores da população comemoravam nas ruas a queda do governo constitucional - a Revolução, como se iria dizer -, outros receberam, chocados e atônitos, o triunfo do golpe(...). Ao se instalar no poder, em 9 de abril, os militares obrigaram a história política brasileira a dar uma reviravolta: com efeito, desmoronava a primeira experiência democrática que o país vinha construindo, aos trancos e barrancos, ao longo de dezoito anos. O golpe iria também mudar radicalmente a vida daqueles brasileiros que não viam motivos para comemorar a derrocada de um governo civil eleito, o qual, mal ou bem, tentava implantar reformas em benefício do povo. Eles acabariam se opondo de distintas maneiras a um regime militar apoiado pelos estratos mais conservadores da sociedade (ALMEIDA; WEIS, 1998, p. 323).
\end{abstract}

Cumpriram mandatos de presidente ao longo do regime os generais ditadores Castelo Branco (1964 - 1967), Costa e Silva (1967 - 1969), Garrastazu Médici (1969 - 1974), Ernesto Geisel (1974 - 1979) e João Figueiredo (1979 - 1985), além de um curto período de atuação de uma Junta Militar quando da transição de governo entre Costa e Silva e Médici.

Foi a partir do final do ano de 1968, com a instituição do Ato Institucional ํㅡ 5 - o Al-5 - que o governo capitaneado pelo general Costa e Silva passou a concentrar ainda mais poderes e a interferir de maneira mais brusca e ativa na produção cultural nacional. 
Sobre o Al-5 e contexto histórico e social vivenciado quando de sua promulgação, Maria Celina D’Araújo, em verbete escrito para a coluna "Fatos e Imagens" da página virtual do Centro de Pesquisa e Documentação de História Contemporânea do Brasil da Fundação Getúlio Vargas, o CPDOC, esclarece que:

\begin{abstract}
Vigorou até dezembro de 1978 e produziu um elenco de ações arbitrárias de efeitos duradouros. Definiu o momento mais duro do regime, dando poder de exceção aos governantes para punir arbitrariamente os que fossem inimigos do regime ou como tal considerados. O ano de 1968, "o ano que não acabou", ficou marcado na história mundial e na do Brasil como um momento de grande contestação da política e dos costumes. O movimento estudantil celebrizou-se como protesto dos jovens contra a política tradicional, mas principalmente como demanda por novas liberdades. O radicalismo jovem pode ser bem expresso no lema "é proibido proibir". Esse movimento, no Brasil, associou-se a um combate mais organizado contra o regime: intensificaram-se os protestos mais radicais, especialmente 0 dos universitários, contra a ditadura. Por outro lado, a "linha dura" providenciava instrumentos mais sofisticados e planejava ações mais rigorosas contra a oposição (D'ARAUJO in: CPDOC, 2017, on-line).
\end{abstract}

Também a esse respeito, o autor Marcos Napolitano (2001, p. 88), em seu livro "Cultura Brasileira", assinala que o intervalo entre os anos de "1969 a 1972 pode ser considerado um período de ajustes entre a produção musical e um contexto cultural e político muito difícil, a partir de 1972 a música brasileira retoma uma certa ofensiva cultural e política contra o regime".

É exatamente nesse contexto inicial de uma inversão de posturas dos artistas e do próprio regime que Belchior e sua obra aparecem no cenário musical nacional, com o lançamento de seu primeiro disco em 1973, o aumento do sucesso em 1976 e seus primeiros atritos com os censores do regime militar, conforme sua música se tornava mais afiada, e seus ataques à ditadura, menos sutis.

Também é o que nos mostra a letra de "Clamor no deserto", do álbum "Coração Selvagem", em que Belchior critica a falta de engajamento de outros artistas, fazendo referência à popular música "Luar do sertão", regravada por inúmeros artistas de sucesso e tida por Belchior como condescendente com o momento político vivido à época, já que a sua letra, de certa forma, trazia um aspecto pueril e deslocado da realidade, como se vê a seguir:

Ei, meus amigos

Um novo momento precisa chegar

Eu sei que é difícil começar tudo de novo

Mas eu quero tentar

Minha garota não me compreende

Mosaico - Volume 10 - № 17 - Ano 2019 
Belchior e o regime militar brasileiro: autoritarismo estatal e a migração inter-regional em suas letras

E diz que, desse jeito, eu apresso o meu fim
Fala que o pai dela é lido e corrido
E sabe que a América toda é assim
Quem me conhece me pede que seja mais alegre
É que nada acontece que alegre meu coração
Dá no jornal, todo dia, o que seria o meu canto
Mas o negócio é cantar o luar do sertão
Ano passado, apesar da dor e do silêncio
Eu cantei como se fosse morrer de alegria
Sei que não é possível dizer todas as coisas
Nesse feliz ano novo que a gente ganhou
Mas falta só algum tempo para 1-9-8-4
Agora estou em paz: o que eu temia, chegou

O caráter de contestação de "Clamor no deserto" também se torna explícito pela menção ao livro "1984" (1949), clássica obra distópica sobre totalitarismo político, do escritor britânico George Orwell.

A manobra política constituída pelo Al-5 igualmente representou uma espécie de "carta branca" para os atos do líder e da alta cúpula do governo seguinte, o presidente general Garrastazu Médici, tido por muitos como o mais cruel e violento presidente em todo o período de existência do regime. Foi logo após o governo de Médici que Belchior se lançou profissionalmente na música, o que pode explicar sua revolta e necessidade de mudança desde o primeiro passo dado em sua carreira.

Tal revolta, entretanto, deveria estar camuflada nas entrelinhas dos versos das canções, justamente em decorrência das engrenagens de supervisão e retaliação do mecanismo político vigente, numa adaptação aqui explicada nas palavras de Maria Gouvêa:

\footnotetext{
O compositor necessitava utilizar recursos linguístico-discursivos que possibilitassem a veiculação das mensagens de maneira implícita e, ao mesmo tempo, preservar sua face. É importante registrar, também, que a compreensão dessas mensagens não era acessível a todas as pessoas e que permitiam outras leituras, em caso de censura ou interrogatório. Assim, o compositor optava por uma ou outra, conforme a conveniência do momento. Nesse período, cada palavra, cada expressão implícita ou explícita era importante para a construção do sentido da canção e continha um valor ideológico (GOUVÊA, 2014, p. 31).
}

Essa necessidade de esconder os verdadeiros significados da palavra e a limitação imposta pelo regime são exploradas por Belchior em "Como se fosse pecado" - música que deveria ter sido lançada em "Coração Selvagem", mas que acabou barrada pela censura e só foi compor o álbum "Todos os sentidos" -, na qual ocorre o seguinte desabafo do artista: 
Por enquanto, o nosso canto é entre quatro paredes

Como se fosse pecado, como se fosse mortal

Segredo humano pro fundo das redes

Tecendo a hora em que a aurora for geral

Por enquanto, estou crucificado e varado

Pela lança, que não cansa de ferir (...)

Mas quando o canto for tão natural como o ato de amar

Como andar, respirar, dar a vez à voz dos sentidos (...)

Quem haverá que aguente tanta mudez sem perder a saúde?

A palavra era um dom, era bom, era conosco, era uma vez...

Felicidade, arma quente, com coisa quente é que eu brinco

Dessa forma, resta claro que os órgãos de censura da ditadura atuavam de maneira implacável com a produção de Belchior. A título de exemplificação, mais da metade das músicas lançadas em "Coração Selvagem" havia sido censurada apenas alguns meses antes. Apenas as faixas "Coração selvagem”, "Paralelas”, "Galos, noites e quintais" e a regravação de "Todo sujo de batom" escaparam do crivo proibitivo dos censores, com destaque para a música "Como se fosse pecado", que teve sua gravação definitivamente proibida no álbum, sendo lançada apenas no ano seguinte, no disco "Todos os Sentidos", como é possível comprovar no seguinte documento: 
Belchior e o regime militar brasileiro: autoritarismo estatal e a migração inter-regional em suas letras

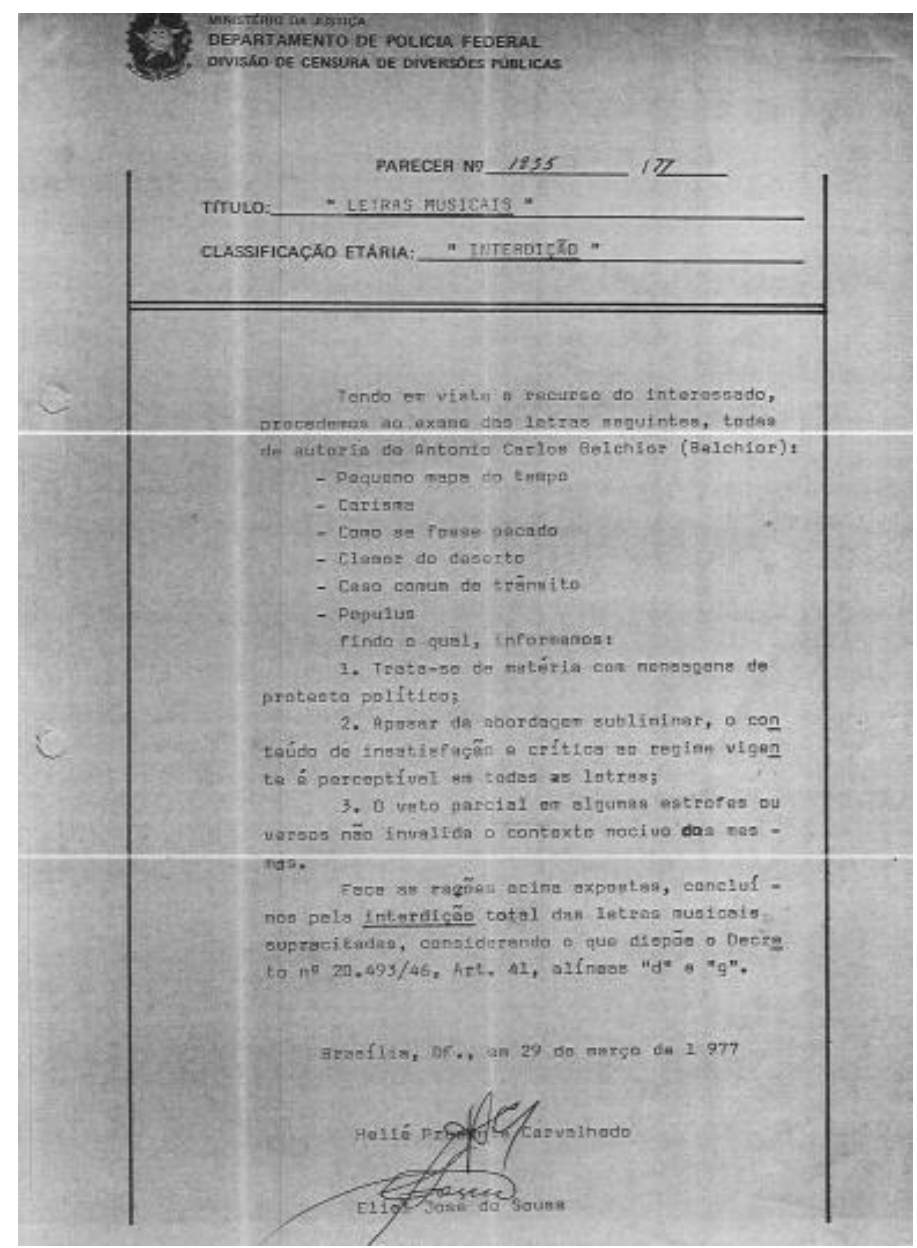

Figura 1- Parecer n 1235/77 - Divisão de Censura de Diversões Públicas Fonte: SILVA, 2015, p. 58, anexo B.

É no álbum "Alucinação", porém, que a obra de Belchior se mostra mais contundente contra a ditadura e os militares, em disco que aparece em 1976, justamente no período inicial da transição "lenta, gradual e segura" para a democracia, conforme lema encampado pelo governo do general Geisel. Tal contundência está presente num dos destaques do álbum, a canção em ritmo folk "Não leve flores":

Não cante vitória muito cedo, não

Nem leve flores para a cova do inimigo

Que as lágrimas do jovem

São fortes como um segredo

Podem fazer renascer um mal antigo

Tudo poderia ter mudado, sim

Pelo trabalho que fizemos - tu e eu

Mas o dinheiro é cruel

E um vento forte levou os amigos

Para longe das conversas, dos cafés e dos abrigos

E nossa esperança de jovens

Não aconteceu, não, não 
Palavra e som são meus caminhos pra ser livre

E eu sigo, sim

Faço o destino com o suor de minha mão

Bebi, conversei com os amigos ao redor de minha mesa

E não deixei meu cigarro se apagar pela tristeza

Sempre é dia de ironia no meu coração

Tenho falado à minha garota

Meu bem, difícil é saber o que acontecerá

Mas eu agradeço ao tempo

O inimigo eu já conheço

Sei seu nome, sei seu rosto, residência e endereço

A voz resiste, a fala insiste: você me ouvirá

A voz resiste, a fala insiste: quem viver verá

Belchior se inseriu no contexto da ditadura por usar suas músicas como instrumento ativo de posicionamento político e ideológico, sendo, em contrapartida, afetado pelo governo ditatorial, especialmente através da censura imposta. Cabe ressaltar, no entanto, que o mesmo não foi exilado: ficou no país, mas, em algumas de suas canções, era possível ver a figura do brasileiro perseguido que precisou deixar o país no papel do eu lírico, como em versos de "Voz da América", na qual consola "Quem teve que partir para um país distante / Não desespere da aurora, recupere o bom humor", ou na letra de "Tudo outra vez", expressa a seguir:

Há tempo, muito tempo

Que eu estou longe de casa

E nessas ilhas cheias de distância

O meu blusão de couro

Se estragou

Ouvi dizer num papo da rapaziada

Que aquele amigo que embarcou comigo

Cheio de esperança e fé

Já se mandou

Sentado à beira do caminho

Pra pedir carona

Tenho falado à mulher companheira

Quem sabe lá no trópico

A vida esteja a mil

E um cara que transava à noite

No "Danúbio azul"

Me disse que faz sol na América do Sul

$E$ nossas irmãs nos esperam

No coração do Brasil

Minha rede branca

Meu cachorro ligeiro

Sertão, olha o Concorde

Que vem vindo do estrangeiro

O fim do termo "saudade"

Como o charme brasileiro

De alguém sozinho a cismar

Gente de minha rua 
Belchior e o regime militar brasileiro: autoritarismo estatal e a migração inter-regional em suas letras

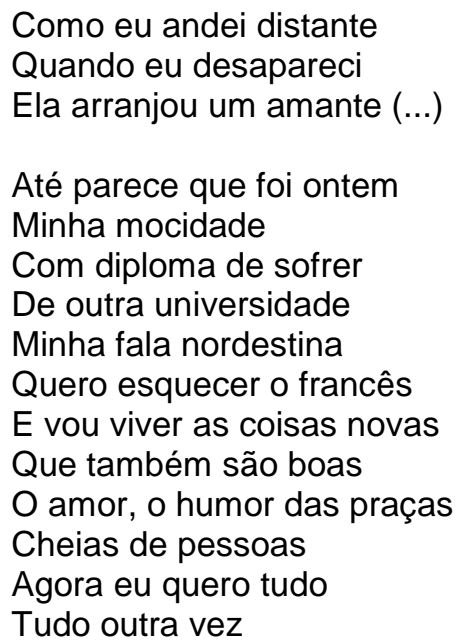

Algumas das referências contidas na supracitada letra são esclarecidas pelo biógrafo de Belchior, o jornalista Jotabê Medeiros, quando diz acerca de "Tudo outra vez":

\begin{abstract}
Deduz-se, pelas referências da letra da música, que o exilado que relata seus sentimentos foi embora do país quando ainda era estudante, que saiu do Nordeste e que passou a viver na França, sem escolha. O cara que transava de noite no Danúbio Azul, nome da valsa de Strauss, pode ser tanto referência a um cabaré de folias ligeiras quanto a um passeio por Viena durante o exílio. Há outra referência à cultura francesa e à cultura literária de Belchior: 'Sentado à beira do caminho' evoca o poema 'Ma Bohème (fantasie)', de Rimbaud, provavelmente no tema da partida, da sensação de liberdade" (MEDEIROS, 2017, p. 118 - 119).
\end{abstract}

Acerca da atividade política de Belchior, e talvez como uma das explicações para que Belchior não tenha sido exilado no período, Medeiros (2017, p. 106) ainda afirma que o músico "nunca gostou de ser ponta de lança de militância contra o regime de exceção, nunca assumiu essa condição. Sua abordagem de política sempre foi mais consoante com a retomada do indivíduo, mais Mikhail Bakunin do que Marx e Lênin".

Tal consideração do biógrafo de Belchior vai ao encontro da ideia presente na letra de "Como o diabo gosta", na qual Belchior declara certa proximidade com o pensamento anarquista ao proceder com uma reflexão sobre o período ditatorial vivido:

Não quero regra nem nada

Tudo tá como o diabo gosta, tá

Já tenho este peso, que me fere as costas

E não vou, eu mesmo, atar minha mão

O que transforma o velho no novo

Bendito fruto do povo será

E a única forma que pode ser norma

Mosaico - Volume 10 - № 17 - Ano 2019 
É nenhuma regra ter

É nunca fazer nada que o mestre mandar

Sempre desobedecer

Nunca reverenciar

O temor pela repressão ditatorial se fazia representar constantemente nas letras de Belchior, e dois exemplos claros disso são as canções "Populus", na qual a vida e a morte de um cachorro servem como metáforas para a população brasileira que vivia sob a tutela do regime militar, e "Pequeno mapa do tempo", em que Belchior demonstra todo o seu receio com o uso da palavra "medo" por dezenas de vezes. Ambas as músicas, inclusive, dialogam com o poema "Congresso Internacional do Medo", de autoria de Carlos Drummond de Andrade.

Conforme ocorria a transição política no Brasil, os novos trabalhos de Belchior caminharam no sentido de uma crítica social e histórica mais geral, diversa, o que antes era especialmente voltado ao cotidiano repressivo, excludente, carente de direitos e de extrema dificuldade para o cidadão comum brasileiro. Tal crítica, por muitas vezes, foi construída de maneira velada - embora nunca sem a onipresente atitude irônica do compositor -, mas em outras vezes era explícita o suficiente para que Belchior viesse a ter composições completa ou parcialmente proibidas para o lançamento em disco, conforme anteriormente exemplificado através de documento da divisão de censura do Ministério da Justiça.

\section{A migração nordestina na obra de Belchior}

A migração inter-regional se distinguiu como uma das mais proeminentes nuances das dinâmicas sociais do Brasil ao longo de todo o século 20, uma vez que o tema aglutinava assuntos tão diversos quanto desigualdade social, desenvolvimento regional, industrialização, mercado de trabalho, agronegócio, êxodo rural e políticas públicas provenientes de regimes autoritários. Também foi um tema extremamente caro às composições de Belchior, notadamente pela experiência própria do artista como um "retirante da música". A seguir, são classificados os três principais períodos de migração atingidos pela obra de Belchior.

O primeiro período ocorreu a partir do pós-Segunda Guerra Mundial, em consequência do desenvolvimento industrial brasileiro - nesse ponto, com contribuição da própria dinâmica de guerra, uma vez que a entrada do Brasil no conflito se deu, dentre outros fatores, após intensa barganha por investimento junto aos países 
Belchior e o regime militar brasileiro: autoritarismo estatal e a migração inter-regional em suas letras

"aliados", especialmente com financiamento proveniente dos Estados Unidos -, a ampliação do modelo econômico capitalista no país, a expansão da chamada "fronteira agrícola" brasileira, especialmente para as regiões Centro-Oeste e Sul, e o crescimento urbano experimentado nas duas principais cidades do país, Rio de Janeiro e São Paulo, metrópoles nas quais Belchior viveu após se mudar do Ceará e que servem de sede para inúmeras passagens retratadas em suas composições.

O segundo, vivenciado no Brasil entre as décadas de 1960 e 1980, atinge em cheio o período mais prolífico da carreira do cantor cearense, e se caracteriza pela manutenção do viés já presente no primeiro momento histórico de migração, que se reforça pela intensificação das desigualdades regionais e pelo desenvolvimento da infraestrutura do país, especialmente na área de transportes, facilitando e tornando cada vez mais viáveis as movimentações feitas pelos migrantes, inclusive com ampla participação e sustentação estatal.

O terceiro e último período de migração brasileira refletido no trabalho de Belchior foi o registrado ao longo da década de 1980, marcado pelo surgimento de novos polos de atração de migrantes no país, em decorrência da desconcentração espacial das indústrias brasileiras - além do crescimento do setor de serviços nas regiões mais urbanizadas do Brasil - e pela relativa diminuição da tendência presente nas décadas anteriores, já num contexto de transição democrática.

Uma das consequências diretas dessa migração foi a inversão de parte do contingente populacional nordestino para as demais regiões brasileiras, interferindo na proporção dessa população com relação à totalidade do país, como ressaltam Wilson Fusco e Ricardo Ojima:

\footnotetext{
Na segunda metade do século XIX, o Nordeste era a região mais populosa do Brasil e sua população representava quase a metade dos habitantes do país. Mais especificamente, conforme dados do Censo de 1872, a população do Nordeste correspondia a $46,7 \%$ do total nacional. A partir de então, os registros mostram um constante declínio nessa participação até atingir os atuais $27,8 \%$ da população brasileira (FUSCO; OJIMA, 2014, p.12).
}

Abordando mais detalhes sobre tal dinâmica migratória brasileira, bem como sobre alguns de seus impactos, Francisco Luna e Herbert Klein nos ensinam que:

A maior disponibilidade de empregos nas cidades e nas regiões mais ricas as oportunidades para estudar e a melhora dos serviços sociais foram fatores que contribuíram para impulsionar a migração em massa ocorrida no Brasil no fim do século XX. Por outro lado, a crescente mecanização do campo e o

Mosaico - Volume 10 - № 17 - Ano 2019 
declínio da agricultura de subsistência em todo o país também colaboraram para esse êxodo rural. Até 1960, a maioria da população ainda morava no campo. (...) Estima-se que, nos vinte anos transcorridos de 1960 a 1980, aproximadamente 27 milhões de brasileiros tenham migrado para a cidade (KLEIN; LUNA, 2014, p. 43-44).

Alguns aspectos da vida nesses centros urbanos foram explicitados por Belchior na canção "Pequeno perfil de um cidadão comum", composta em parceria com Toquinho e lançada em 1979, no disco "Era uma vez um homem e o seu tempo", como se vê em:

Era um cidadão comum, como esses que se vê na rua
Falava de negócios, ria, via show de mulher nua
Vivia o dia e não o sol, a noite e não a lua
Acordava sempre cedo, era um passarinho urbano
Embarcava no metrô, o nosso metropolitano
Era feito aquela gente honesta, boa e comovida
Que caminha para a morte pensando em vencer na vida
Era feito aquela gente honesta, boa e comovida
Que tem no fim da tarde a sensação da missão cumprida

Outra composição que aponta diversas das características acima descritas é "Monólogo das grandezas do Brasil", de "Paraíso", álbum lançado em 1982 e que se manteve até recentemente como inédito no formato de CD. Nessa canção, Belchior descreve o desemprego como a principal motivação que levaria o migrante a deixar sua terra natal, além de ilustrar quais cidades faziam parte do imaginário migrante notadamente São Paulo e Rio de Janeiro, tidas como "Eldorados" - e conclui com a frustração do eu lírico perante o que se deparava nesses locais, uma desilusão que se acentuou no terceiro período migratório aqui descrito, um migrante que desejava voltar ao seu lugar de origem, cruelmente preso nas grandes cidades pela impossibilidade financeira do regresso, o que o impediria de finalizar o ciclo da migração malsucedida, como nos mostra o excerto trazido a seguir:

Tá faltando emprego

Neste meu lugar

Eu não tenho sossego

Eu quero trabalhar

Já pensei até em passar a fronteira.

Eu vou pra São Paulo e Rio

Eldorados de além-mar

A estrada é uma estrela pra quem vai andar (...)

Vou voltar pro Norte semana que vem

Deus já me deu sorte, mas tem um porém

Não me deu a grana pra eu pagar o trem 
Belchior e o regime militar brasileiro: autoritarismo estatal e a migração inter-regional em suas letras

Em "Notícia de terra civilizada", do álbum "Baihuno", a temática da migração preenche a totalidade da composição, que demonstra a nostalgia contida nas lembranças do autor sobre a sua terra natal, e reitera o ideal de transformação de vida adjacente ao movimento migratório, a desilusão após o não cumprimento das expectativas criadas antes da mudança, e o onipresente desejo de alguma súbita e providencial conquista financeira que possibilite o retorno ao lugar de pertencimento do migrante sertanejo, caracterização do migrante ressaltada pela menção ao final à frase mais famosa da obra clássica "Os sertões" (1984), de autoria de Euclides da Cunha e originalmente lançada em 1902, que narra a Guerra de Canudos e versa sobre as ditas características gerais da população do sertão nordestino, conforme se demonstra a seguir:

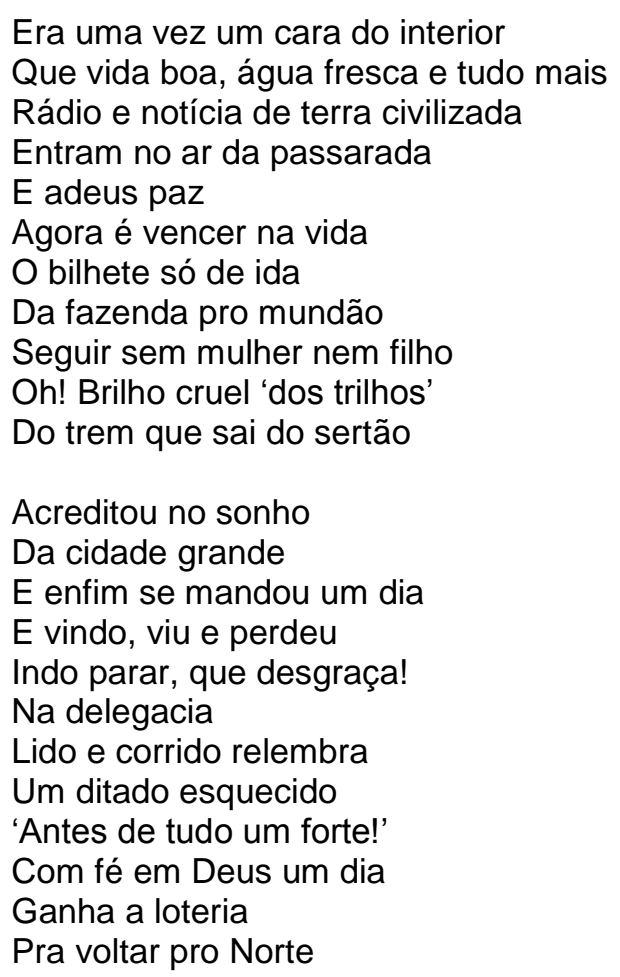

Das características da canção reproduzida acima se depreende a resiliência associada por Belchior ao retirante nordestino, como este repete em "Como Nossos Pais", nos versos "Vou ficar nesta cidade / Não vou voltar pro sertão / Pois vejo vir vindo no vento / O cheiro da nova estação".

Em contrapartida, o aspecto da desistência da vida no Sudeste e do retorno ao local de origem é novamente abordado por Belchior em "Caso comum de trânsito", ao narrar "Minha namorada voltou para o norte / Ficou quase louca e arranjou um 
emprego muito bom" e em "Princesa do meu lugar" - canção jamais lançada em disco por Belchior -, nos versos "Ao ver que o cajueiro anda florando / Saiba que estarei voltando, princesa do meu lugar / (...) Não há pranto que apague / Dos meus olhos o clarão / Nem metrópole onde eu não veja / O luar, o luar do sertão".

Em "Conheço o meu lugar", o compositor fala em tom de desabafo sobre a região e alguns dos estigmas ligados aos seus habitantes: "Nordeste é uma ficção! / Nordeste nunca houve, não! / Eu não sou do lugar dos esquecidos / Não sou da nação dos condenados / Não sou do sertão dos ofendidos / Você sabe bem: conheço o meu lugar!".

Acerca da histórica associação da região Nordeste à migração interna brasileira, comenta George Martine no prefácio ao livro "Migrações nordestinas no século 21":

No Brasil, nenhuma região tem sido mais afetada por processos migratórios que o Nordeste, fazendo desta diáspora um capítulo central da história nacional. Conhecido, há mais de um século, como a terra da arribação, o Nordeste está acostumado a perder grande parte de seus filhos e filhas para outras regiões. Em consequência, a região é vista como o símbolo e a materialização da migração (MARTINE, 2014 apud FUSCO; OJIMA, 2014, p.5).

O tom nostálgico que embala as recordações do migrante rural que vive na cidade grande também ocupa um espaço central na letra de "Galos, noites e quintais", lançada em "Coração Selvagem":

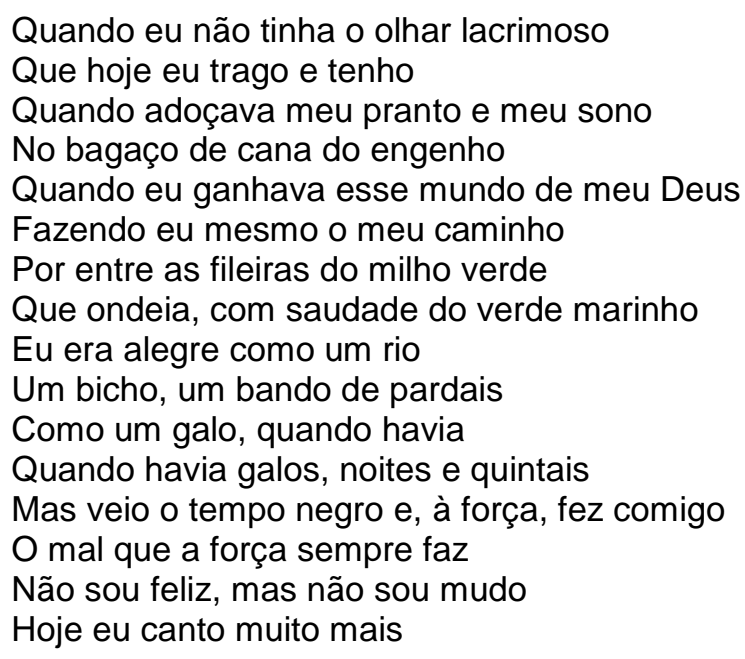

A preocupação do compositor com as angústias e os obstáculos que a nova vida na cidade grande - e, muitas vezes, hostil aos recém-chegados - impunha aos migrantes nordestinos se tornou uma presença recorrente em suas canções, que não 
Belchior e o regime militar brasileiro: autoritarismo estatal e a migração inter-regional em suas letras

se limitava aos discos lançados quando de sua chegada ao Sudeste, uma vez que também se fazia presente em trabalhos lançados quando o compositor já ocupava posição destacada e confortável no meio musical nacional, como é o caso da música "Baihuno", do álbum de mesmo nome lançado em 1993, na qual Belchior aproveitava pra revisitar episódios do início de sua trajetória musical, por meio de recados enviados a indivíduos de seu antigo convívio:

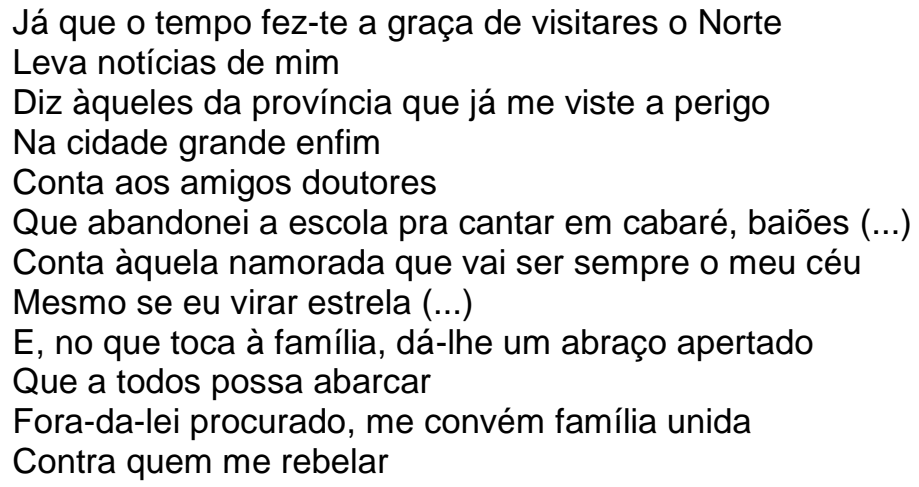

Tal característica de revisitação da trajetória não era exatamente uma novidade do Belchior já consagrado por crítica e público: na canção "Fotografia 3×4", de "Alucinação", o artista passeia pela sua chegada ao eixo Rio-São Paulo, tece críticas sociais, provoca Caetano Veloso e os tropicalistas e dá mostras do estado de vigilância e repressão vigentes durante o regime militar, num enquadramento que inclui na letra, música e interpretação um forte teor emocional.

Encontra-se, a seguir, a transcrição da quase totalidade da composição:

Eu me lembro muito bem do dia que eu cheguei Jovem que desce do Norte pra cidade grande Os pés cansados e feridos de andar légua tirana De lágrimas nos olhos de ler o Pessoa

E de ver o verde da cana

Em cada esquina que eu passava um guarda me parava

Pedia os meus documentos e depois sorria

Examinando o 3x4 da fotografia

E estranhando o nome do lugar de onde eu vinha

Pois o que pesa no Norte, pela lei da gravidade Disso Newton já sabia: cai no Sul, grande cidade São Paulo violento, corre o Rio que me engana Copacabana, Zona Norte e os cabarés da Lapa onde eu morei Mesmo vivendo assim, não me esqueci de amar Que o homem é pra mulher e o coração pra gente dar Mas a mulher, a mulher que eu amei Não pôde me seguir não

Esses casos de família e de dinheiro eu nunca entendi bem

Mosaico - Volume 10 - № 17 - Ano 2019 
Veloso, o sol não é tão bonito pra quem vem do Norte e vai viver na rua

A noite fria me ensinou a amar mais o meu dia

E pela dor eu descobri o poder da alegria

E a certeza de que tenho coisas novas

Coisas novas pra dizer

A minha história é talvez

É talvez igual a tua, jovem que desceu do Norte

Que no Sul viveu na rua

E ficou desnorteado, como é comum no seu tempo

E que ficou desapontado, como é comum no seu tempo

E que ficou apaixonado e violento como eu como você (...)

Eu sou como você que me ouve agora

Em "Ter ou não ter", de "Todos os sentidos", Belchior fala essencialmente de si, do início de sua aventura longe do Ceará e da exploração sofrida no trabalho com o qual garantia o mínimo sustento financeiro, algo recorrente nas condições informais dos empregos obtidos por muitos migrantes sem qualificação acadêmica para postos de trabalho de hierarquia mais alta, conforme a letra a seguir:

\footnotetext{
Quando eu vim para a cidade, eu ganhava a minha vida Ave-pássaro cantando na noite do cabaré.

E era mais pobre do que eu a mulher com quem dividia Dia e noite, sol e cama, cobertor, quarto e café.

O Nordeste é muito longe. Ê, saudade.

A cidade é sempre violenta.

Pra quem não tem pra onde ir, a noite nunca tem fim.

O meu canto tinha um dono e esse dono do meu canto

Pra me explorar, me queria sempre bêbado de gim.

O patrão do meu trabalho era um tipo de mãos apressadas

Em roubar, derramar sangue de quem é fraco, inocente.

Tirava o pão das mulheres - suor de abraços noturnos,

Confiante que o dinheiro vence infalivelmente
}

A presença de fortes relatos da vida do cidadão comum nordestino nos grandes centros urbanos, bem como as dificuldades impostas nos novos locais de moradia, o preconceito sofrido, as condições precárias - e algumas vezes degradantes - nos empregos obtidos, a saudade de sua terra e as grandes preocupações financeiras posicionam a obra de Belchior como um importante instrumento de interpretação da realidade dos migrantes brasileiros, a partir de um legítimo lugar ocupado pelo compositor, com várias das canções com essa temática extrapolando a liberdade poética e se mostrando como verdadeiras passagens biográficas que davam vazão aos sentimentos do compositor. 
Belchior e o regime militar brasileiro: autoritarismo estatal e a migração inter-regional em suas letras

\section{Considerações finais}

Diante do exposto ao longo deste trabalho, pode-se concluir que a prolífica obra de Antônio Carlos Belchior foi de grande impacto para a sociedade brasileira e para o campo musical nacional. Com o significado do seu trabalho, Belchior consolidase no rol dos grandes representantes da MPB e da música brasileira do século XX.

Tratou-se de um artista com imensa capacidade de promover debates relevantes com toda a sorte de campos temáticos, em composições em que se pode aprender desde sobre a personalidade desse artista - inclusive com eventuais contradições em suas letras -, a até mesmo sobre a intensa competição inerente ao campo musical.

As críticas levantadas por Belchior ao regime ditatorial civil-militar cumprem, ainda, um papel como ilustração para as barbaridades e sistemáticas violações de Direitos Humanos cometidas no período, transformando-se em verdadeiros hinos da juventude e música de protesto brasileiras. A fidedignidade das denúncias confere às composições um certo status de documentos históricos do período e das violências estatais praticadas durante a ditadura de 1964 - 1985 no Brasil.

Sua morte - ocorrida em 30 de abril de 2017, na cidade de Santa Cruz do Sul, RS, após o rompimento da artéria aorta, quando tinha 70 anos e seu paradeiro ainda se mantinha desconhecido do grande público - causou furor nacional e instigou um necessário exercício de interpretação e mensuração do impacto de sua obra para a música e a sociedade brasileira.

Artigo recebido em 10 out. 2019. Aprovado para publicação em 28 nov. 2019.

\section{Referências Bibliográficas}

ALMEIDA, Maria Hermínia Brandão Tavares de; WEIS, Luiz. Carro-zero e pau-dearara: o cotidiano da oposição de classe média ao regime militar. In: História da vida privada no Brasil, v. 4: contrastes da intimidade contemporânea. São Paulo: Editora Schwarcz, 1998. p. $319-410$.

ANDRADE, Carlos Drummond de. Congresso Internacional do Medo. In: Antologia Poética. 12. ed. Rio de Janeiro: José Olympio. 1978. p. 108-109. 
BELCHIOR, Antônio Carlos. Alucinação. Polygram/Philips, 1976. LP. . Baihuno. MoviePlay, 1993. CD. . Cenas do próximo capítulo. Paraíso/Odeon, 1984. LP. . Coração selvagem. Warner, 1977. LP. . Era uma vez um homem e o seu tempo. Warner, 1979. LP. . Paraíso. Warner, 1982. LP.

. Princesa do meu lugar. Música sem lançamento em álbum. Disponível em: <

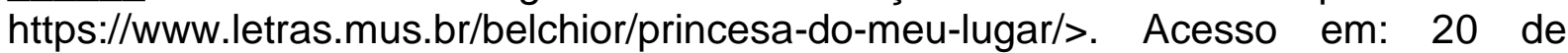
setembro de 2019.

. Todos os sentidos. Warner, 1978. LP.

CUNHA, Euclides da. Os sertões: campanha de Canudos. São Paulo: Ática, 1998.

D'ARAUJO, Celina. Fatos e imagens - O Al-5. In: FGV CPDOC. Fatos e Imagens: artigos ilustrados de fatos e conjunturas do Brasil. Disponível em < https://cpdoc.fgv.br/producao/dossies/Fatoslmagens/Al5>. Acesso em 29 de setembro de 2019.

FUSCO, Wilson; OJIMA, Ricardo (org.). Migrações nordestinas no século 21: um panorama recente. São Paulo: Editora Edgard Blucher, 2014.

GOUVÊA, Maria. 'Você corta um verso, eu invento outro': o poder linguísticodiscursivo da música de protesto no período da ditadura militar". Revista Literatura e Autoritarismo, Santa Maria, n. 23, p. 22-32, 2014. Disponível em $<$ https://periodicos.ufsm.br/LA/article/view/13954/pdf>. Acesso em 15 de setembro de 2019.

KLEIN, Herbert; LUNA, Francisco. População e Sociedade. In: REIS, Daniel Aarão (coord.). Modernização, ditadura e democracia: 1964 - 2010. Rio de Janeiro: Objetiva, 2014, p. $31-73$.

MARTINE, George. Prefácio. In: FUSCO, Wilson; OJIMA, Ricardo (org.). Migrações nordestinas no século 21: um panorama recente. São Paulo: Editora Edgard Blucher, 2014, p. $5-8$.

MEDEIROS, Jotabê. Belchior - Apenas um rapaz latino-americano. São Paulo: Todavia, 2017.

NAPOLITANO, Marcos. A História depois do papel. In: PINSKY, Carla Bassanezi (org.). Fontes Históricas. São Paulo: Contexto, 2010, p. 235 - 289.

. Cultura brasileira: utopia e massificação (1950-1980). São Paulo: Contexto, 

letras

REIS, Daniel Aarão. A vida política. In: REIS, Daniel Aarão (coord.). Modernização, ditadura e democracia: 1964 - 2010. Rio de Janeiro: Objetiva, 2014, p. 75 - 125.

SILVA, Eder. Alguns pré (textos) nas canções de Belchior num Brasil ufanista. $55 \mathrm{f}$. Trabalho de Conclusão de Curso (Monografia de licenciatura em Letras Português Inglês). Departamento de Letras, Universidade Federal Tecnológica do Paraná. Pato Branco, 2015.

Disponível em

http://repositorio.roca.utfpr.edu.br/jspui/bitstream/1/8051/1/PB_COLET_2015_1_04.p df>. Acesso em 04 de outubro de 2019. 